\title{
SMART GROWTH THROUGH JOINT HIGHWAY AIR RIGHTS AND TRANSIT- ORIENTED DEVELOPMENT
}

\author{
ANDREAS L. SAVVIDES \\ Department of Architecture, University of Cyprus.
}

\begin{abstract}
As part of a broader smart growth strategy transportation nodes, from their initial inception, have been organizing forces in a city's master-planning process. This role has become more important with time and with the addition of modes of transportation, such as buses and trams, which are being co-housed in these structures. At the same time, driving and the use of highways have been a fact of life for many people who live in circumstances that demand car travel. Major highways and mass transit links generally do a good job of connecting primary destinations. It is the connections from primary destinations to networks of local streets and bus routes that can be problematic. At the community level, local governments concerned with the smart growth and fiscal potential of their communities are beginning to establish development policies to promote connectivity. At the project level, urban designers and developers are increasingly asked to establish good connectivity to adjacent properties as well as within their developments. In these efforts, local governments provide further incentives for new development to locate near transit lines and stations, with design guidelines for projects aimed at improving access to transit and all the integrated or adjacent amenities. This paper attempts to discern the qualitative aspects with regards to the urban design strategies employed and also to present socioeconomic indicators that support financial viability of this kind of development model through the utilization of case studies in Boston, MA and Seattle, WA, citing projects that were completed in the mid to the late 1980s (completed before the recessions of 1989-1992 and 1999-2001) as well as examining and comparing the effect of these developments on socioeconomic indicators in the decades before, during and after project completion.
\end{abstract}

Keywords: highway air rights, right-of-way bridging, smart growth, transit-oriented development, urban fabric re-stitching.

\section{INTRODUCTION}

The suburbanization of cities has placed many residents in locations that are far less accessible than their prior residences, requiring motorized travel. Job accessibility levels decline dramatically following these moves, matched by increased motorized travel and longer commute durations. Relocating to an area near a mass transit park-and-ride station, however, was found to moderate losses in job accessibility and for many, encourage switches from nonmotorized travel to transit commuting [1]. Given this Transit-Oriented Development (TOD) holds considerable promise for placing rapidly suburbanizing Chinese cities on a more sustainable pathway. Fuelling the centrifugal movement of people and jobs in central cities, these developments - especially when they find correspondence to limited access highway exits - have seen rising disposable incomes for their households, as well as higher property values, given the highest and best use of land at these nodal points.

A major goal of urban design, especially as part of smart growth strategies in urban cores, is to reduce automobile dependence in order to address issues of viability and sustainability. Long-term data from cities around the world appear to show that there is a fundamental threshold of urban intensity (residents and jobs) of around 35 per hectare where automobile dependence is significantly reduced [2]. A design technique for the socioeconomic viability of city centres is suggested in the form of transit-oriented urban design and its beneficial 
connections to the utilization of air rights in highway corridors, especially at locations where urban highway and mass transit networks overlap.

Consequently, TOD has emerged as a popular and influential planning concept [3, 4], whereby physical design is an important aspect and a crucial means of coordinating relatively intensive land uses and multiple transportation modes. Moreover, TOD projects depend on good urban design to coordinate transportation types, mix land uses and create an appealing public space, all in a limited area. If TOD projects are to be successful and meet the goals of policy makers, transportation engineers, planners, developers and, of course, the general public, greater understanding is needed of the successes and failures of TODs in terms of their broader urban design practices and financial viability forecasts.

To further support this point, a recent study by ULI and PWC [5] rated TOD as a top real estate, while the government and transit agencies are placing more and more attention on TOD. The study is concerned with three major rail stations in the East San Francisco Bay Area that have been developed along the Transit Adjacent Development - Transit Development model: Downtown Berkeley, Hayward and Fremont, where Hayward and Fremont are suburban settings that are in the process of redeveloping around their train stations. While this sample is not large enough to be considered statistically valid, it shows how variation of urban design in three station precincts may affect the travel behaviour and vehicle ownership of local residents.

In addition, data from an STPP study [6] indicate that transportation expenditures - in the United States at least - account for 17.5\% of the average household's budget. The proportion of household expenditures that is devoted to transportation has grown as use of the automobile has grown. On the other hand, TOD reduces transportation costs, increases travel choice and reduces land paved per capita [7]. TOD can increase transit service efficiency, resulting in improved performance and cost-effectiveness. It can help create more liveable communities, meaning that neighbourhoods become physically and socially more desirable places to live. These benefits are reflected in higher property values and increased commercial activity, which can result in increased tax revenue [8]. It is this point that this paper attempts to illustrate and to emphasize that TOD can be a catalyst for urban redevelopment and help create more accessible communities, where people can live, work and have access to services more efficiently and by less travel [9].

Further research indicates that where transit creates more efficient land use, each transit passenger-mile represents a reduction of 3 to 6 automobile vehicle-miles [10,11]. Each transit passenger-mile represents 1.4 to 9.0 miles of reduced vehicle-miles while Renne et al. [12] found that in major U.S. metropolitan regions transit commuting declined dramatically during the last three decades (from 19.0\% in 1970 to $7.1 \%$ in 2000), but in the 103 TODs within those regions transit commuting increased from $15.1 \%$ in 1970 to $16.7 \%$ in 2000 , a $11 \%$ growth rate. The percentage of transit commuting was over three times higher in TODs compared to averages for maturing, heavy rail regions and over twice as much for TODs in new start, light rail regions. Reconnecting America [13] - a national organization focused on the link between transportation and community development - studied demographic and transport patterns in 'transit zones', defined as areas within a half-mile of existing transit stations in U.S. cities. It found that households in transit zones own an average of 0.9 cars, compared to an average of 1.6 cars in the metro regions as a whole. This study also found that automobile travel is also much lower in transit zones. Only 54\% of residents living in transit zones commute by car, compared to $83 \%$ in the extended region as a whole. More residents commute by car in the regions with small and medium-sized systems ( $72 \%$ and $77 \%$, respectively) 
than in the large and extensive systems (65\% and 49\%, respectively). Schlossberg et al. [14] found that many transit stations are not optimally located to maximize pedestrian access and that automobile-oriented streets (wide, with heavy and fast traffic) can create a significant barrier to walking.

This is especially true at the nodal points where highway rights-of-way cross networks of mass transit corridors, local streets and bicycle and pedestrian pathways, such as are to be found in the siting, planning and design of effective TODs. Consequently, the relationship of physical planning to form, use and density in the design and development of TODs and its influence on human behaviour and travel is a key element of many land use and transportation planning. Prior research [15] indicates that high-density urban development leads to decreased travel and thus sustainable mobility, one of the cornerstones of smart growth. A better understanding of the relationships among environment, transportation and urban planning and design and the social, economic and demographic characteristics and household attitudes as described in this study may help explain how to leverage the benefits of coupling the joint development of highway corridors with TODs so as to improve the quality of the urban fabric that sustains community life.

\section{LEARNING FROM RAIL TRANSIT: AN APPROACH TO EMULATE}

In investigating the potential of new highway joint development of mixed-use structures coupled with multi-modal stations to act as catalysts for regeneration, such as those to be found in TODs, reference is made to Button [16] who claims that economic activity - exhibits of which will be presented in the comparative analysis of the selected case studies later on in the paper - is often clustered and these clusters tend to be around interchange and terminal sites. This concentration is particularly pronounced where fixed track transport is involved or where common resources are used in the actual movement. Some common features that make urban transport terminals and interchanges worth considering in their own right - and independently of the links in the transport network and potentially the highway - in terms of promoting economic development are that:

- they are located near concentrations of population (but also generate negative environmental effects);

- they involve almost without exception multi-modal facilities (and potentially highway on/ off ramps);

- they usually have a long physical life when completed.

These interchanges featuring an increased number of users made up of commuters who are either stopping for services at or passing through the intermodal station areas result in a spatial impact multiplier. This multiplier is a product of the synergies created in the economic production and job creation at a specific location as a result of the intensification of locating higher densities of multiple uses within or adjacent to a said location. This then has become the usual way of assessment of the effect that a transport terminal or interchange development can have on any area, as shown in the illustration in Fig. 1 (left) by Bernick and Cervero [17]. Similarly, the graph in Fig. 1 (right) by Button [16] offers a fairly standard depiction of the employment impacts of transport investment over time. There are direct jobs created in association with the construction of the terminal or interchange, the indirect effects of the construction on local industries and the longer-term spill-over effects from new activities moving to the area [18]. However, the risks of financial cost overruns are considerable in the context of major transport 

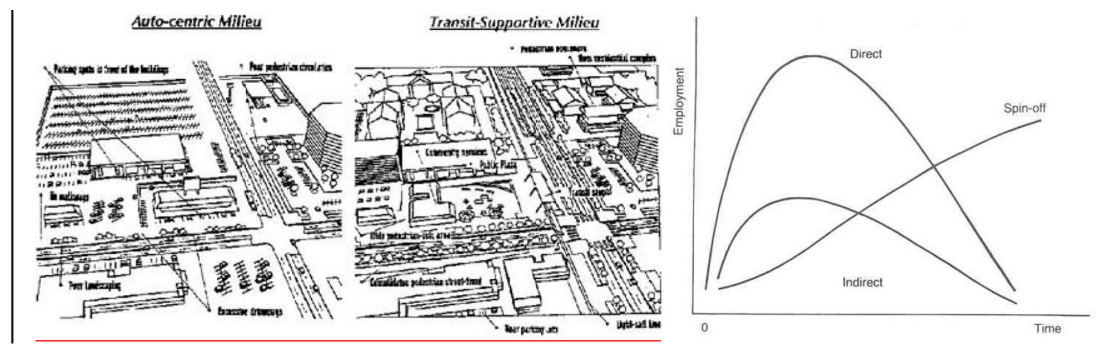

Figure 1: Left: Visual representation of design approaches towards converting an autooriented commercial district to a transit-oriented neighbourhood (Source: [17]). Right: Employment impacts of transport investment over time (Source: Button et al. [16]).

investments, and the role of risk sharing between the public and private sectors should be carefully considered. The idea is to seed private investments through public funding commitments. Design principles that are rooted in market realities, recognizing that design upgrades cost money, sometimes a good deal of it, are also becoming more commonplace.

\section{COUPLING HIGHWAY AND MASS TRANSIT INFRASTRUCTURE}

In the cases of coupling highway and mass transit infrastructure, as demonstrated by the case studies in Boston, MA and Seattle, WA in Sections 3.1. and 3.2, the main challenge facing the public and private development partnerships was how to retrofit and convert existing autooriented urban spaces into transit-oriented hubs and neighbourhoods. For the most part, upfront public improvements are called for - like landscaping, street furniture, sidewalks and bus shelters - that signal to developers a public commitment to turn around a declining area (Fig. 1 left, above). Grid-iron streets of a super-block scale without continuous sidewalk networks, for example, are unlikely to entice many suburbanites to give up their cars. Collectively, transit-sensitive design elements can create fundamentally different milieus in and around transit stations that make transit riding a pleasant experience [19]. To provide a good environment for residential development or pedestrian access it is therefore important that such facilities be properly located, designed and managed to minimize conflicts with the transportation corridors, and also to take full advantage at the points of modal change or the venues of social exchange.

Sustainable transport in its support of smart growth strategies should promote human health and provide the opportunity for social interaction and an enriched urban experience. Three changes are required to achieve these goals. The first is a reduction in the need to travel and the distance that people have to travel particularly for those essential trips to work, school and shops, which according to Thorne et al. [20] 'account for $46 \%$ of journeys of more than one mile and since $70 \%$ of these "essential journeys" are made by car, the potential for reduction is considerable'. Second is the need to change the mode of travel. For people, this means changing from cars to foot or cycle for short journeys and to public transport for longer journeys. Even in existing circumstances such a change can already result in savings on journey times. Third is the need to make cars more energy efficient and less polluting. When land was available and cities were seen as overcrowded and unhealthy, planning encouraged dispersal away from the old centres to new and usually lower-density settlements on the edges. The growing popularity of cars in the second half of the twentieth century reinforced dispersal of 
activity away from the downtown to the suburb [21]. The suburbanites' subsequent demand for more and bigger roads came increasingly to dominate urban planning and public policies that shaped new and existing communities.

At this point and given the extent to which cars have become integrated into people's daily lives as well as urban planning and design practices, there needs to be a radical reversal of current policies catering to cars. More environmentally friendly automobiles and their rightof-way should be better integrated with proposed mass transit systems under the roof of multi-modal stations, such as the ones resulting from coupling the limited access points to urban highways and their correspondence with mass transit hubs, utilizing the air rights associated with these locations. If this occurs in the case of the latter scenario, studying the relationship between density and transport will be a key consideration [22]. Public transport services that provide an alternative to the private car will only work where there are sufficient people: hence the need for clusters of higher density within walking distance of public transport stops coupled with highway interchanges as exemplified by the case studies in Boston and Seattle described in Sections 3.1 and 3.2 [23]. The closer these transit interchanges occur to already dense city cores, the more innovative multi-modal stations and associated developments need to be to accommodate demand for space [24]. In the case studies examined further in Sections 3.1 and 3.2, the need for clustering and accommodating uses in intensely dense urban conditions manifests itself in complex yet innovative sectional solutions enveloped in mid- and high-rise proposals. Furthermore, horizontal mixed use development provides zones of different activity. Mixing uses in this way ensures that a range of services is within a reasonable distance.

According to Thorne et al. [20], built-in flexibility is essential to ensure that proposed projects can be adapted to meet future demands, a strategy in accordance with smart growth strategic planning. Design has an important role to play especially as the continuing role of the car cannot be readily denied. But should it be allowed into and through the city? The building of a by-pass, by taking traffic away from a town centre, may erode its life and activity. Walkable neighbourhoods are fine but one needs to be aware of creating ones that do not turn their backs on their surroundings. The same holds true of pedestrian shopping thoroughfares where denial to car access can sometimes lead to retail vacancies if the means of accessing the destination are not taken up by alternative modes [25]. Thus, the handling of highway routes and the potential to develop their air rights is a design challenge that must be accounted for very carefully. Part of the data utilized herein has come from interviewing the development teams responsible for the successful examples of this development typology and also with the redevelopment expectations of local residents. The case studies presented are both located in major metropolitan areas on the east and the west coast of the United States, in Boston and Seattle respectively, and they are mixed-use facilities integrated with multimodal transit stations and with direct access via on-and-off ramps to limited access highways.

\subsection{Copley place in Boston}

Copley Place, the second air rights project to be completed in Boston in the mid-1980s, is located in the heart of Boston across from Copley Square and connected to the Back Bay/ South End Multi-Modal Transit Centre. It provided infill in an otherwise underutilized area occupied by a highway ramp and provided further amelioration to the issue of community disruption in the area by adding additional commercial, office and residential square footage as part of its programme, as shown in Figs 2 and 3. 

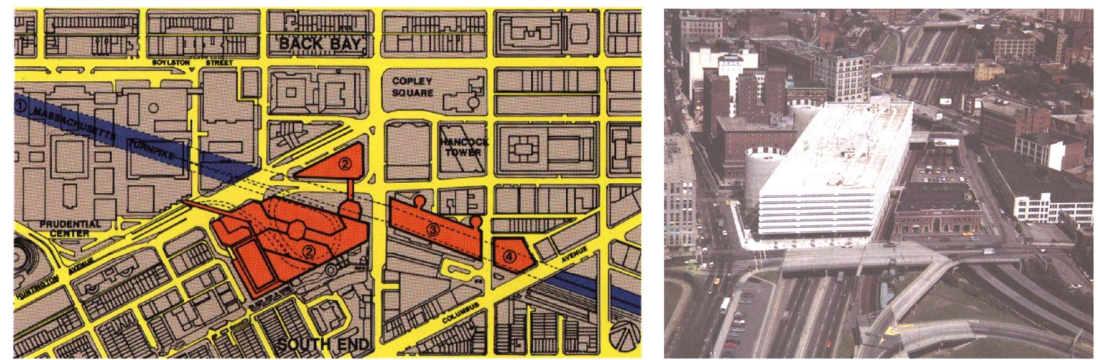

Figure 2: Left: Copley Place \& Hancock Retail-Garage proposed on air rights above highway and railway right-of-way. Right: Hancock Garage erected on 'Double-Ts' and incorporating direct access to parking and an on-ramp to the Massachusetts Turnpike/Interstate-90. (Source: [26]).
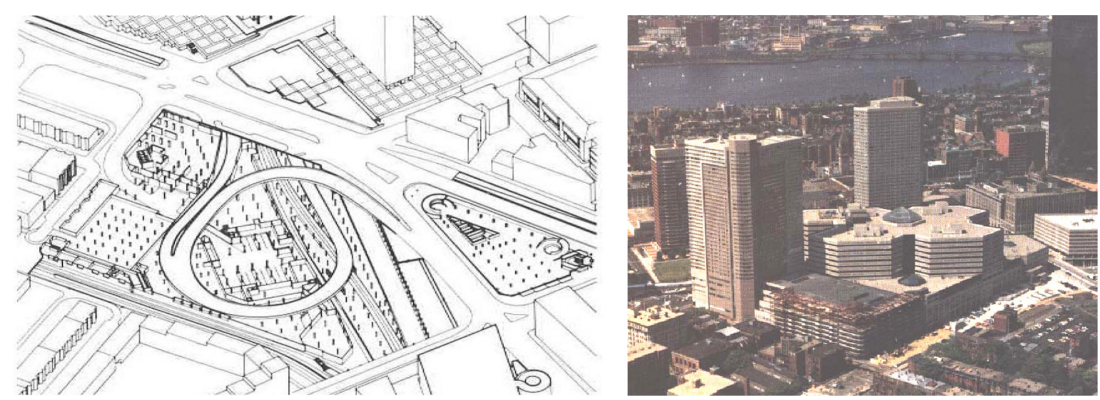

Figure 3: Left: Copley Place Development incorporates two exit ramps from the Massachusetts Turnpike providing a direct connection to its residential, commercial and retail uses. Right: Copley Place and Hancock joint developments are connected to the Back Bay-South End Station with connecting service to busses, the subway and commuter rail systems and Amtrak. (Source: [27])

\subsection{Key tower in Seattle}

The Key Tower (Gateway) project, completed in Seattle in the late 1980s and accommodated by the Washington State Department of Transportation, had a lot of support from the Highway Commission as a means to put right-of-way back to work. In this case, air rights over express ramps on and off Interstate 5 close to Seattle's Central Business District were utilized to construct an office tower with a substantial retail component and connected to local mass transit, in an otherwise blighted and underutilized area of the city (Fig. 4).

\section{URBAN AND ECONOMIC DEVELOPMENT INDICATORS}

In the maps and tables below the census tracts around the major air rights developments in the cities of Boston and Seattle (City of Boston: Fig. 5; City of Seattle: Fig. 6; and Table 1) are outlined, historically tracing results from the 1970 s to the $1990 \mathrm{~s}$, a period that covers conditions before, during and after development completion of these projects, in order to compare before-and-after effects in the targeted areas. 

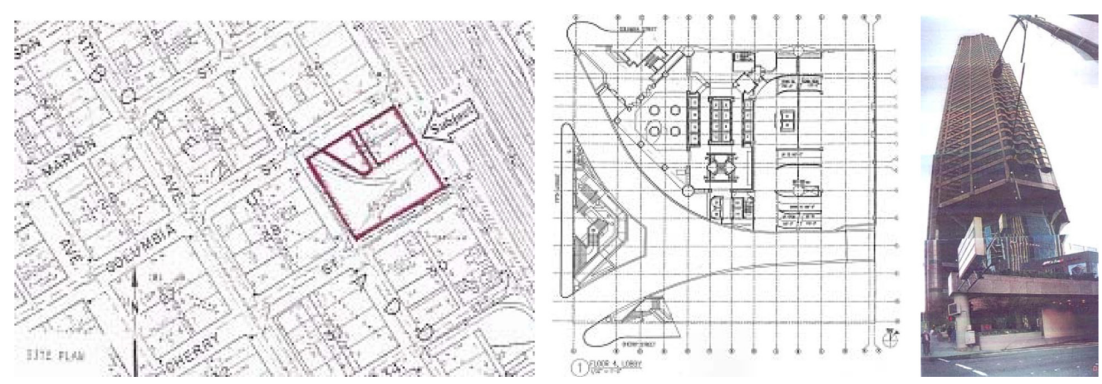

Figure 4: Left: Site plan for the Key Tower joint development in Seattle showing block survey of the target and adjacent blocks. The site was encumbered by reversible on-and-off ramps to Interstate-5 to the northeast. Centre: Ground floor plan with superimposed structural grid indicating necessity for costly transfer beams at the building base so as to carry the tower above. Right: Perspective of the Key Tower. The structural base houses parking and makes direct connections to mass transit system at street level.
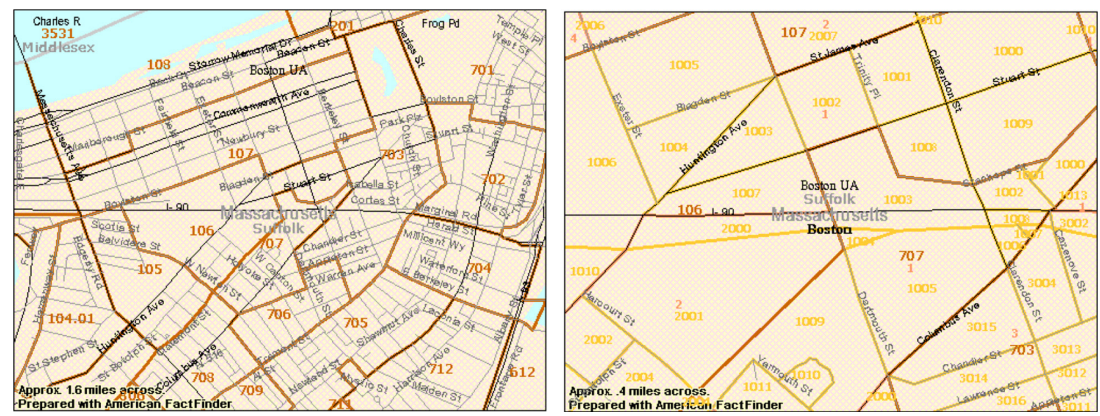

Figure 5: Census 2000 - Suffolk County/City of Boston by census tracts and blocks; on the left a map of Tracts No. 105, 106 and 107 for Back Bay and No. 703, 706, 707 and 708 for South End in the broader context of their neighbourhoods; on the right zooming in to the project area.
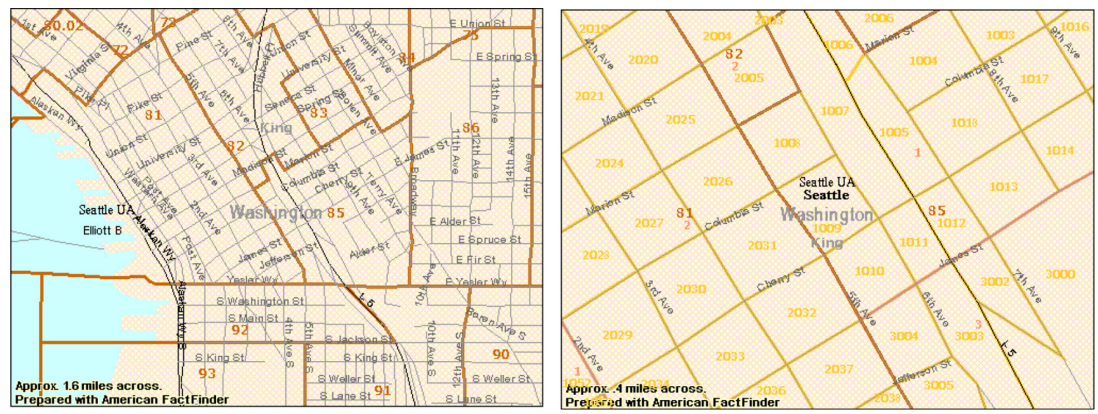

Figure 6: Census 2000 - King County/City of Seattle by census tracts and blocks; on the left a map of Tracts No. 081, 082 and 085 for Downtown Seattle in the broader context of the neighbourhood; on the right zooming in to the project area. 
Table 1: Comparative values for property value, rental rate and family income in the respective target areas in Boston and Seattle, Corrected For Inflation (CFI).

\begin{tabular}{|c|c|c|c|c|c|c|c|}
\hline 1 & & $1970(\$)$ & $1980(\$)$ & $1990(\$)$ & $\begin{array}{l}1970 \\
(\mathrm{CFI} \$)\end{array}$ & $\begin{array}{l}1980 \\
\text { (CFI\$) }\end{array}$ & $\begin{array}{l}1990 \\
(\mathrm{CFI} \$)\end{array}$ \\
\hline 3 & BOSTON & & & & & & \\
\hline 4 & Value (median) & 19800 & 36000 & 160100 & 89822 & 82327 & 214421 \\
\hline 5 & Rent (median) & 126 & 191 & 625 & 572 & 437 & 837 \\
\hline 6 & Income (median) & 7299 & 12530 & 29180 & 33112 & 28655 & 39081 \\
\hline 8 & Back Bay & & & & & & \\
\hline 9 & Value (median) & 40393 & 125000 & 443767 & 183241 & 285859 & 594335 \\
\hline 10 & Rent (median) & 162 & 336 & 827 & 735 & 768 & 1108 \\
\hline 11 & Income (median) & 4464 & 16218 & 35209 & 20251 & 37089 & 47155 \\
\hline 12 & South End & & & & & & \\
\hline 13 & Value (median) & 24084 & 73050 & 380750 & 109256 & 167056 & 509937 \\
\hline 14 & Rent (median) & 95 & 248 & 699 & 431 & 567 & 936 \\
\hline 15 & Income (median) & 4078 & 14697 & 38481 & 18500 & 33610 & 51537 \\
\hline 17 & SEATTLE & & & & & & \\
\hline 18 & Value (median) & 19700 & 65900 & 136500 & 89368 & 150705 & 182814 \\
\hline 19 & Rent (median) & 73 & 163 & 295 & 331 & 373 & 395 \\
\hline 20 & Income (median) & 2945 & 5877 & 10904 & 13360 & 13440 & 14604 \\
\hline 22 & Downtown & & & & & & \\
\hline 23 & Value (median) & 25000 & 50000 & 166667 & 113412 & 223216 & 381146 \\
\hline 24 & Rent (median) & 118 & 233 & 463 & 535 & 533 & 620 \\
\hline 25 & Income (median) & 8712 & 16254 & 29353 & 39522 & 37171 & 39312 \\
\hline
\end{tabular}

Three major categories, household income, household value and rental value were also compared against the performance of the city as a whole. The relationships, as presented, provide some evidence as to the revitalization effects of the highway air rights developments as reflected by the rising values in these three categories at a higher rate than that experienced by the city's respective neighbourhoods and in each case as a whole (Figs 7-9 respectively) The phenomenal rise in the case of the Back Bay in Boston, but more so in the South End neighbourhood is the result of gentrification which caused a population shift after project completion, with higher income new residents moving into the neighbourhood and lower income former residents moving further out. 


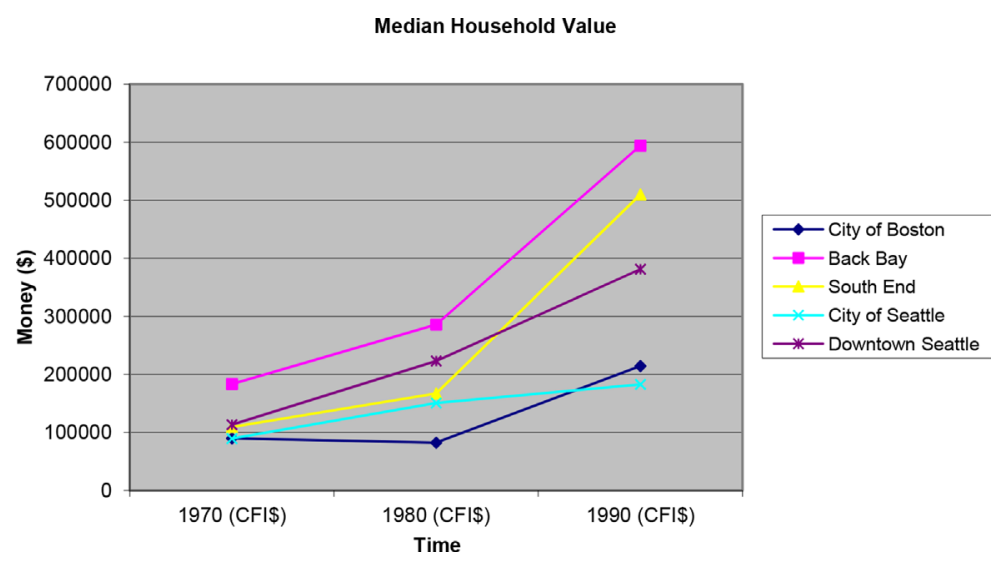

Figure 7: Comparables for Median Household Value in the target period.

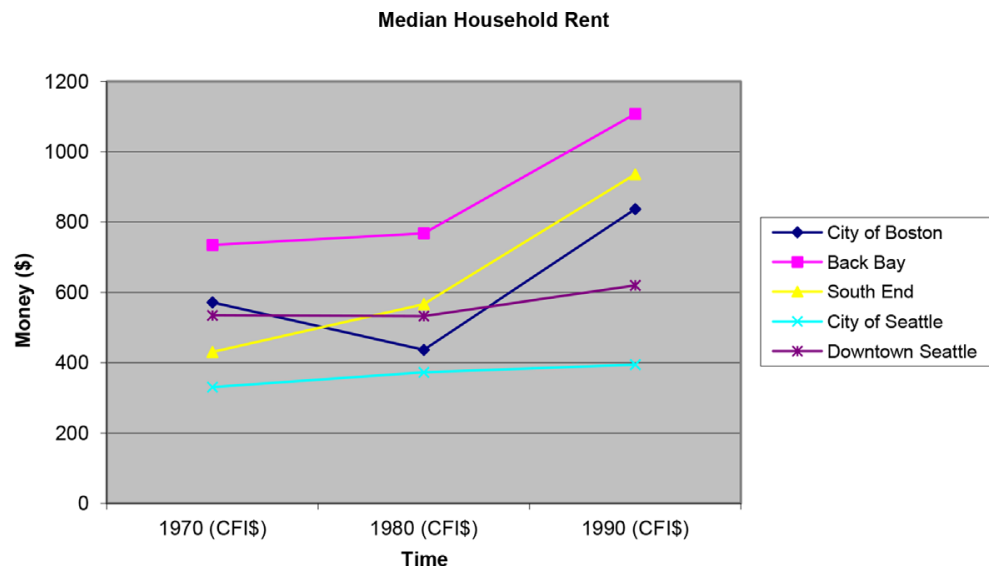

Figure 8: Comparables for Median Household Rent in the target period.

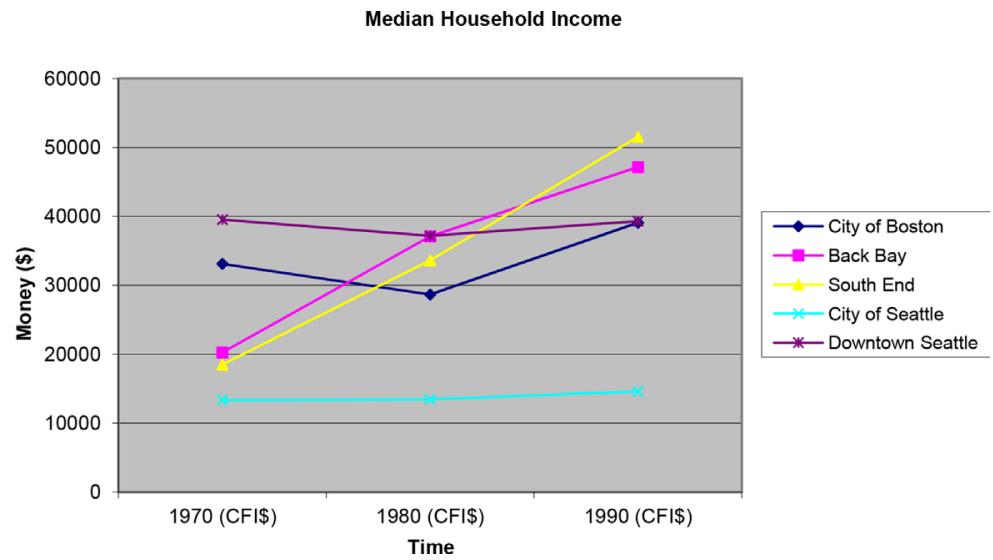

Figure 9: Comparables for Median Household Income in the target period. 


\section{DISCUSSION OF RESULTS AND CONCLUDING THOUGHTS}

In promoting the private use of air space above transportation corridors and transit nodes, while attempting to obtain fair market value for the air rights, a highway agency may use a number of approaches once according to DOT officials it has ensured the financial soundness of the project and the developer [28]. One approach used by the cities of Boston and Seattle involves a study of the transportation corridor to determine the general areas of potential development, followed by more detailed analysis and selection of sites. The use of each site is then specified after considering issues of transit accessibility, highway use, local planning and zoning. Figure 10 shows such a study produced by the Massachusetts Turnpike Authority in collaboration with planners at the Boston Redevelopment Authority and in consultation with similar agencies from adjacent municipalities [29], so as to approach the problem holistically rather than in a piecemeal fashion. The DART in Atlanta [30] followed a similar path.

The needs of the community and valuation of the development rights may also be performed in order to set the minimum price or lease rate for a public bid. Further, in assessing the public participation in a project, national agencies evaluate the public sector's commitment to joint development and the city's track record on previous projects. In all, public participation has taken a variety of forms in providing incentives, such as:

- Density bonuses, which allow more usable area than existing codes allow, giving the private developer a competitive advantage over adjacent locations.

- Long-term leasing of 'land' (as in man-made deck over the corridor or node), owned by the public sector, at low rates, which avoids the problem of absorbing high costs for land and downtown site assembly.

- Outright grants or long-term government-insured financing at below-market rates, which improves the project's financial feasibility.

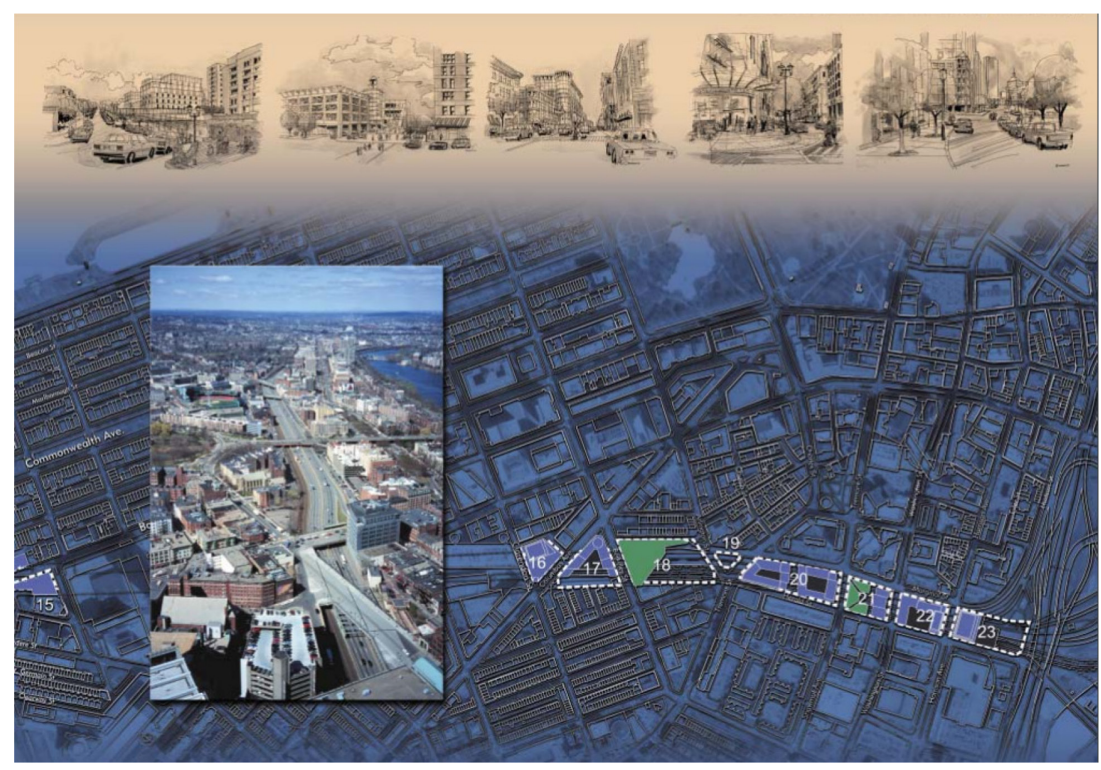

Figure 10: Excerpt from the document entitled 'A civic Vision for Turnpike Air Rights in Boston'. 
- The public sector agreeing to rent space in the project at a guaranteed rate thereby securing a percentage of occupancy and attracting other tenants.

- The abatement of real estate taxes or a reduction in the assessment to reduce annual real estate tax expenses and improve the project's financial feasibility.

- Transferring development rights and air rights to or within the project to allow higher densities and higher floor area ratios on the site.

- National/local income tax incentives, e.g. deducting all construction interest and fees and accelerated depreciation rates to improve a project's financial viability.

- Public agencies providing studies and concepts to help initiate air rights projects and guide potential developers.

However, the fact that private investors may be unable to carry the burden of the entire extra cost of development over the highway has been recognized, both in the case of Copley Place in Boston and of Key Tower in Seattle [31]. Since development of highway air rights returns valuable space to the city or region, it may be reasonable to supplement it with national or local grants (such as the DOT grant for the Key Tower and the UDAG grant for Copley Place) to cover the cost of capital outlay and planning coordination.

Technological innovation and a limited quantity of spatial resources in densely built cities [32] are forcing automobile engineers and highway planners to rethink products - i.e. to make the automobile more environmentally acceptable - and to come up with new ways of designing and managing the urban arterial [33]. In considering the question of managing the urban arterial, transportation and urban planners should study the development potential of strategically located air rights projects at key interchanges of the urban highway network. The physical impact of these interventions erected in the air rights associated with the right-of-way of these urban highways, especially when these are in correspondence with other multi-modal mass transit stations, has been shown to produce an intensive level of development and a ready source of new residents, office occupants, retail customers or hotel guests.

This model could readily be adopted and adapted to include the automobile and the highway as there is a tremendous amount of highway infrastructure already in place and an even greater and increasing number of automobiles that occupy it. If anything, the rising values of the indicators for the case studies in the target areas in Boston and Seattle - before, during and after completion of the joint highway air rights development projects - demonstrate the regenerative potential inherent in the coupling limited access highway on-and-off ramps at the nodal points where they correspond with established or proposed intermodal transit stations in transit-oriented neighbourhoods.

\section{REFERENCES}

[1] Cervero, R. \& Day, J., Suburbanization and transit-oriented development in China. Transport Policy, 15(5), pp. 315-323, 2008. https://doi.org/10.1016/j.tranpol.2008.12.011

[2] Newman, P. \& Kenworthy, J., Urban design to reduce automobile dependence. Opolis, 2(1), pp. 35-52, 2006.

[3] Jacobson, J. \& Forsyth, A., Seven American TODs: good practices for urban design in transit oriented development projects. Journal of Transport and Land Use, 1(2), pp. 5188, 2008.

https://doi.org/10.5198/jtlu.v1i2.67 
[4] Ratnera, K. \& Goetzb, A., The reshaping of land use and urban form in Denver through transit-oriented development. Cities, 30, pp. 31-46, 2013.

https://doi.org/10.1016/j.cities.2012.08.007

[5] Urban Land Institute and PriceWaterhouseCoopers. Emerging Trends in Real Estate, ULI \& PWC: Washington, DC, 2005.

[6] Surface Transportation Policy Project - Centre for Neighbourhood Technology. Driven to Spend, STPP: Washington, DC, 2000.

[7] Cervero, R., Transit-Oriented Development in the United States: Experience, Challenges and Prospects. TCRP Report 102, Transit Cooperative Research Program, Transportation Research Board: Washington, DC, 2004.

[8] Smith, J.J. \& Gihring, T.A. Financing Transit Systems Through Value Capture: An Annotated Bibliography, Geonomy Society: Portland, OR, 2003.

[9] Voith, R., The downtown parking syndrome: does curing the illness kill the patient? Business Review, 1, pp. 3-14, 1998.

[10] Newman, P. \& Kenworthy, J., Sustainability and Cities: Overcoming Automobile Dependence, Island Press: Washington, DC, 1999.

[11] Holtzclaw, J., Does A Mile In A Car Equal A Mile On A Train? Exploring Public Transit's Effectiveness in Reducing Driving? The Sierra Club: San Francisco, CA, 2000.

[12] Renne, J.L., Wells, J.S. \& Voorhees, A.M., Transit-oriented development: developing a strategy to measure success. Research Results Digest, no. 294, National Cooperative Highway Research Program (NCHRP), Transportation Research Board, National Academy Press: Washington, DC, 2005.

[13] Reconnecting America, Center for Transport Oriented Development, available at www. reconnectingamerica.org/html/TOD.

[14] Schlossberg, M., Brown, N., Bossard, E.G. \& Roemer, D., Using Spatial Indicators for Pre- and Post-Development Analysis of TOD Areas: A Case Study of Portland and the Silicon Valley, Mineta Transportation Institute: San Jose, CA, 2004.

[15] Olaru, D., Smith, B. \& Taplin, J., Residential location and transit-oriented development in a new rail corridor. Transportation Research Part A: Policy and Practice, 45(3), pp. 219-237, 2011. https://doi.org/10.1016/j.tra.2010.12.007

[16] Button, K., Transport terminals, interchanges and economic development. In Transport and Urban Development, ed. D. Banister, E \& FN Spon: London \& New York, 1995. https://doi.org/10.4324/9780203451328_chapter_17

[17] Bernick, M. \& Cervero, R., Transit Villages in the 21st Century, McGraw-Hill Companies: Columbus, $\mathrm{OH}, 1996$.

[18] Bishop, Z., Transit-Oriented Development: Benefits and Studies, Virginia Ball Center for Creative Inquiry, 2015.

[19] Conservation Law Foundation, available at: www.clf.org/programs.

[20] Thorne, R, Filmer-Sankey, W. \& Alexander, A., Transportation. In Sustainable Urban Design: An Environmental Approach, eds A. Ritchie \& R. Thomas, Spon Press: London, 2003.

[21] Ewing, R., Pedestrian- and Transit-Friendly Design: A Primer for Smart Growth, Smart Growth Network: Washington, DC, 1999.

[22] Fishman, R., The American City in the 21st Century. The Urban Land Institute, Washington DC, 2000. 
[23] Savvides, A.L., Multi-modal transit hubs: enhancing sustainability through joint highway development, Proceedings from the 17th International Conference on Urban Transport and the Environment, 6-8 June 2011, Pisa, Italy. WIT Transactions on the Built Environment, 128, pp. 709-718, 2011.

[24] Thompson, N., Vaulting ambition: air rights buildings. Architect's Journal, 193(26), pp. 47-48, 1991.

[25] Broadhurst, J.V., From highways to skyways and seaways - the intermodal challenge. Public Roads, 68(1), pp. 28-33, 2004.

[26] Jolliffe, M., Highway Air Rights Structures, Zaldastani Associates, Inc: Boston, MA, 1990.

[27] Jolliffe, M., Highway air rights construction adds New Land to Boston. Urban Land, 43(8), pp. 7-9, 1984.

[28] Dunphy, R., Developing Around Transit, The Urban Land Institute: Washington, DC, 2004.

[29] Strategic Development Study Committee. A Civic Vision for Turnpike Air Rights in Boston, BRA: Boston, MA, 2000.

[30] Parkhi, M., Transit Oriented Development: Environmental Planning and Design. Doctoral Dissertation, Department of Environmental Design, University of Georgia, December 2014.

[31] Dunphy, R., Myerson, D. \& Pawlukiewicz, M., Ten Principles for Successful Development Around Transit, The Urban Land Institute: Washington, DC, 2003.

[32] Dittmar, H. \& Ohland, G. (eds), The New Transit town: Best Practices in TransitOriented Development, Island Press, 2012.

[33] Leach, D.M., Context-Sensitive Solutions in Multi-modal Urban Corridor Planning: Arlington, Virginia's Experience, Institute of Transportation Engineers: Washington, DC, 2005. 